\title{
A self-destroying mechanism generated when functional parameters of paint system layers are improved in a non-suitable manner
}

\section{"Self-destroying" mechanismus vyvolaný nevhodnou úpravou zvyšující funkční vlastnosti nátěrového systému}

Mindoš L., Paráková M.

SVÚOM, s.r.o.

E-mail: mindos@svuom.cz

Increasing the functional parameters of coating composition-based protective coatings is a strongly emerging trend. However, there are some limits to the increasing of utility parameters of protective coatings - always where such parameters are opposite to the basic property, which is corrosion protection. The presented study describes a case of a premature failure in the corrosion protection secured by a duplex system that occurred after the paint system had been enriched with an anti-sliding property.

\section{INTRODUCTION}

Where surfaces are finished with organic coatings, investors relatively often require some areas, e.g. parking areas or walking roofs, to be delivered in an anti-sliding version. The overwhelming majority of technologies use additional application of sharp edged grains, mostly based on separated silicate sand, into the layer of a noncured organic coating. Almost always, at least one more coating layer is applied to fix these grains to the substrate. This technology of anti-sliding surface treatment is easy, requiring only one additional step to be done, i.e. as much uniform as possible gritting of separated sand into a wet coating layer.

This procedure was used to secure anti-sliding surface treatment of hot-dip galvanised steel walking roofs in the manufacture of mobile living containers. The coating system consists of one $2 \mathrm{~K}$-epoxy primer and one $2 \mathrm{~K}$-polyurethane coating finish. Both layers were applied using the airless spray technique. Unfortunately, within a short period, after less than 2-year exposure to an outdoor atmosphere, the surface treatment failed - the 2-layer
Zvyšování funkčních parametrů ochranných vrstev na bázi nátěrových hmot je silně rozvijejici se trend. Zvyšováni užitných parametrů ochranných vrstev má však svá omezení a to vždy tam, jsou-li v protikladu se základní užitnou charakteristikou, kterou je protikorozni ochrana. Prezentovaná studie rozebirá př́pad, $k d y$ došlo $k$ předčasnému selháni protikorozni ochrany duplexního nátérového systému, když byl nátěrový systém obohacen o protiskluzný parametr.

paint system peeled off, the zinc coating corroded, and the steel substrate also corroded intensively - see Fig. 1.

\section{EXPERIMENTAL WORK}

\section{Optical microscopy of the delaminated anti-sliding paint system}

Optical microscopy of a cross section performed vertically to the paint layers was used to analyse samples taken from delaminated anti-sliding paints of mobile living containers. The paint system was evaluated in detail in such areas where a step change occurred in the paint system thickness due to the application of sand grain (see Fig. 7 and 8).

\section{SEM microscopy of the delaminated anti-sliding paint system}

The delaminated anti-sliding paint system was also evaluated by means of scanning electron microscopy (SEM) to verify negative effects of the step change in the paint system thickness within short segments. 


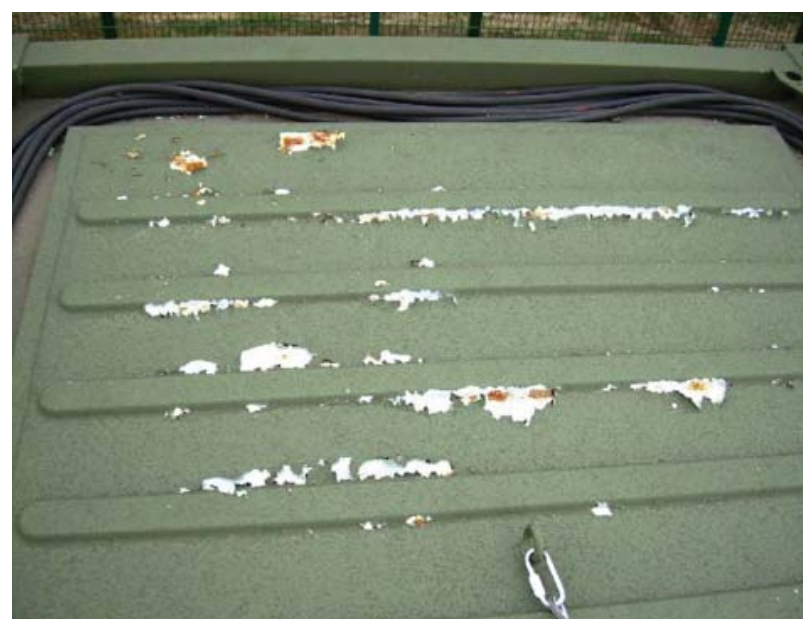

a)

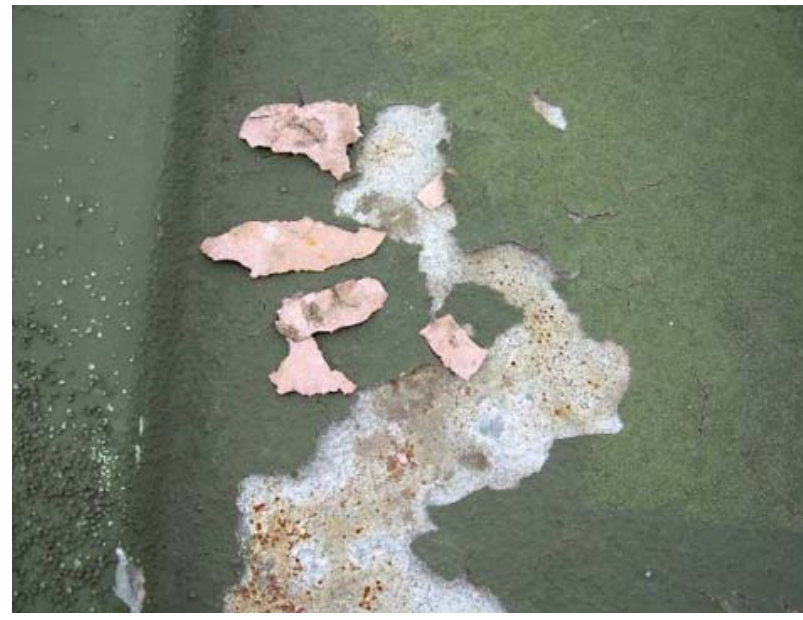

c)

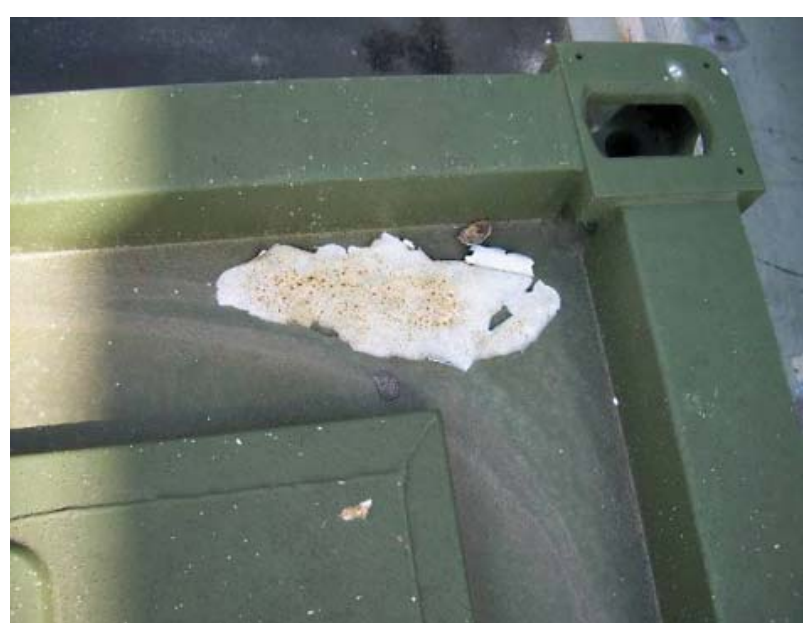

b)

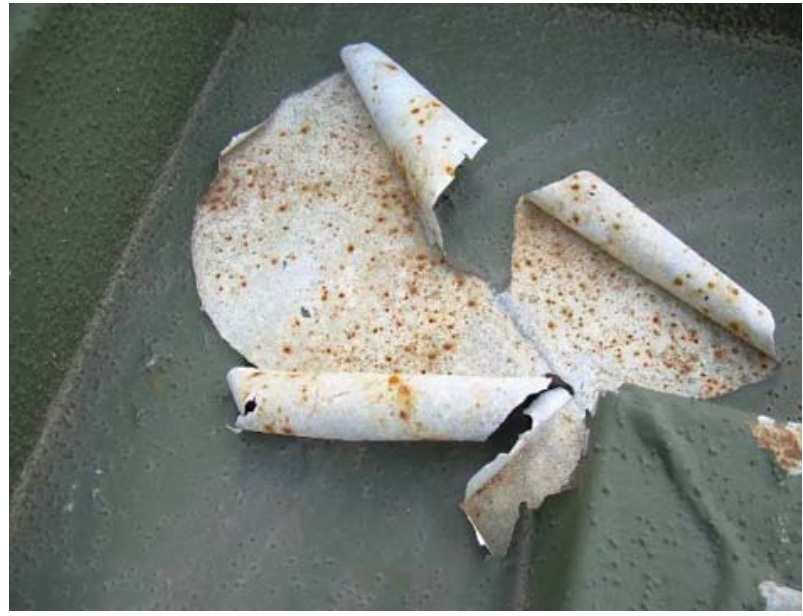

d)

Fig. 1. Roof panel - defects of the surface treatment Obr. 1. Střešní panel - defekty v povrchové úpravě

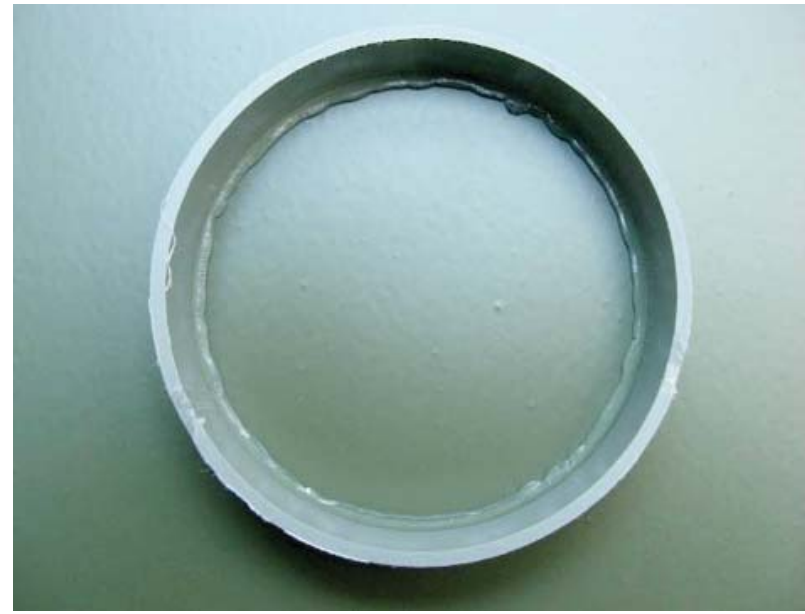

Fig. 2. Original paint system on glass Obr. 2. Pưvodní nátěrový systém nanesený na skle

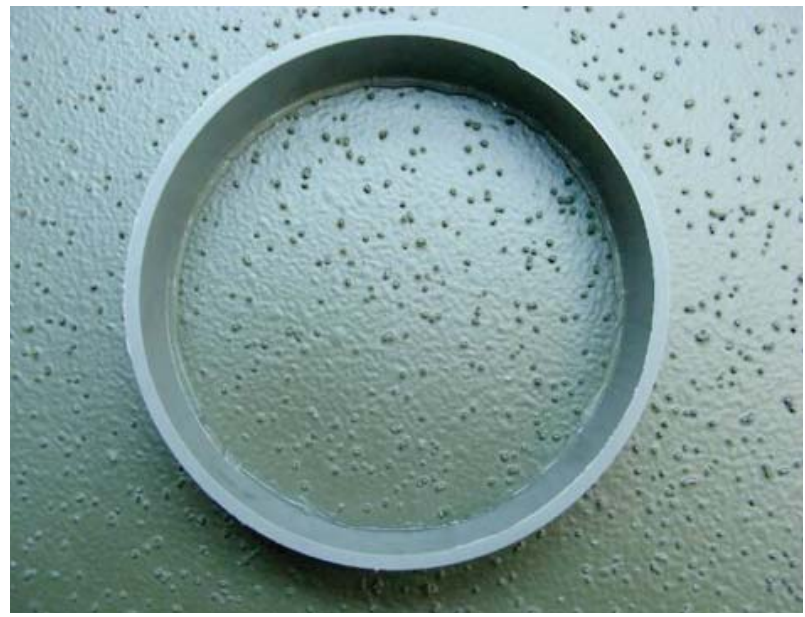

Fig. 3. Modified paint system on glass Obr. 3. Upravený nátěrový systém nanesený na skle 


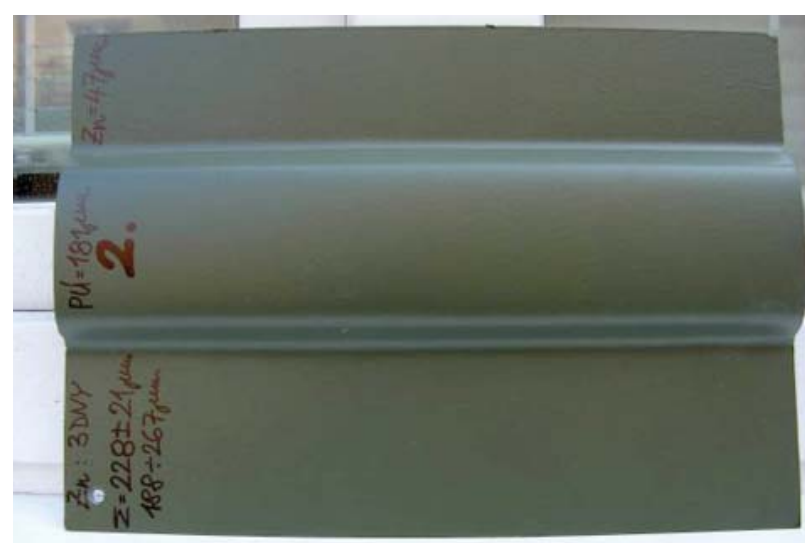

a)

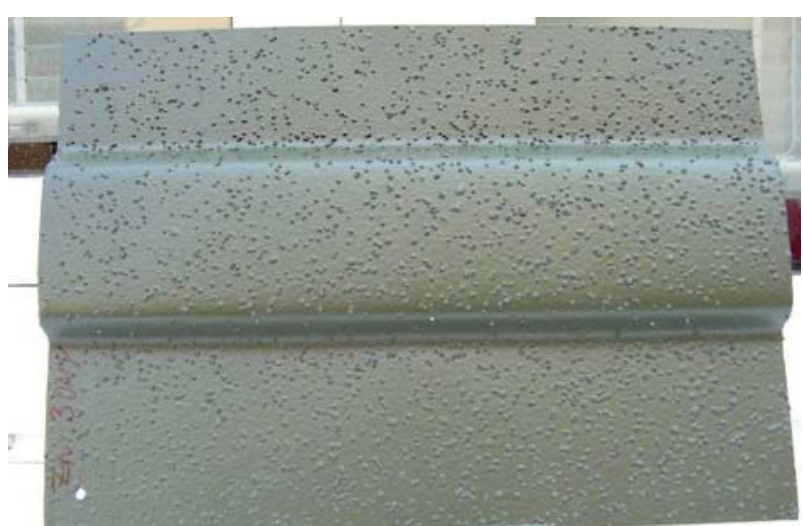

b)

Fig. 4. The original and modified paint systems applied on steel sheets Obr. 4. Původní a upravený nátěrový systém nanesený na ocelovém plechu

\section{Comparative visualisation of delamination intensity in different paint systems by means of water vapour diffusion}

As every paint system is unique and any modification of its original composition always causes changes, comparative visualisation of paint system delamination was performed, using a newly developed method when two paints of a thickness of $3 \mathrm{~mm}$ each were applied on float glass so that it would be possible to study the reasons for the premature failure of the anti-sliding paint system. The same rings were marked on both paint systems which were applied on the glass and exposed to cyclic combined effects of changing levels of relative humidity $(<10 \%$ to $100 \%)$ and temperatures ranging from $-10{ }^{\circ} \mathrm{C}$ to $+25^{\circ} \mathrm{C}$ as is typical for outdoor environments (Figs. 2 and 3 ).

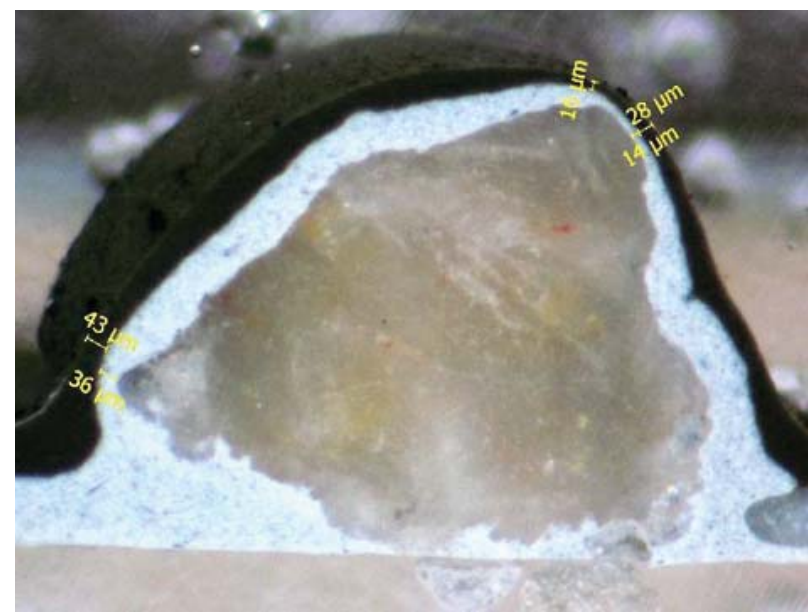

Fig. 5. Non-uniform distribution of the paint system layer thickness near to a sand grain

Obr. 5. Nerovnoměrná tlouštka vrstvy nátěrového systému v okolí zrna písku

\section{Comparison of delamination intensity in different paint systems after accelerated corrosion tests}

To clarify and verify the destructive mechanism arising from modification of the paint system formulation (an anti-sliding version filled with sand), comparative corrosion tests were performed for two types of paint systems - the original and anti-sliding versions, applied on profiled galvanised steel sheets (Fig. 4). Both paint systems were long-term exposed in neutral salt spray test according to ISO 9227 for a period of 50 days $(1,200 \mathrm{hrs})$. After the corrosion test, visual evaluation of the paints was conducted, and the substrate material was also assessed after the exposed paint layers had been removed.

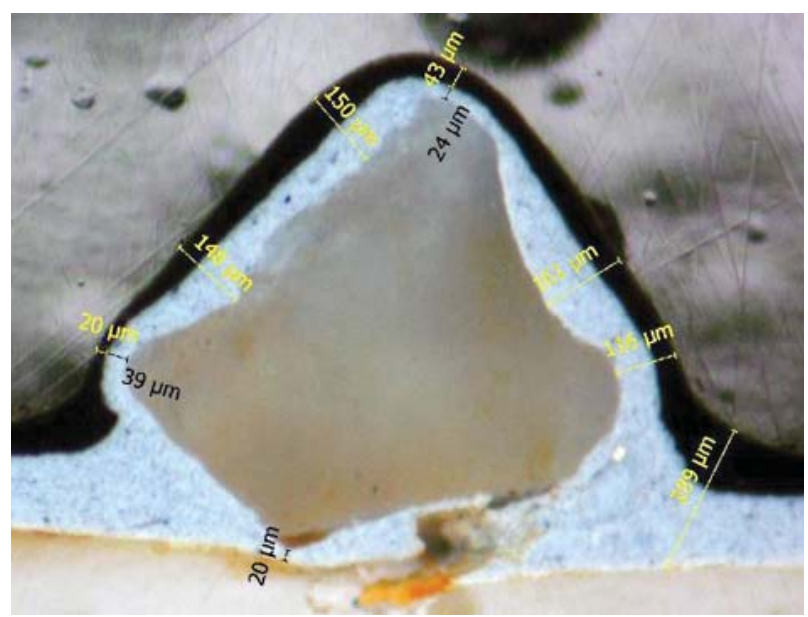

Fig. 6. A layer thickness of $39+20 \mu \mathrm{m}$ on the upper part of a sand grain protruding above the substrate sheet

Obr. 6. Vrstva s tloušt́kou 39+20 um na vrchní části zrna písku vystupující nad podkladovou ocel 


\section{RESULTS}

\section{Optical microscopy of the delaminated anti-sliding paint system}

It was found that the most intensive changes in the thickness of a paint system occurred on the top of sand grains, alongside with the lowest values of the thickness of a coating layer, and on the contrary, the higher thickness of a coating layer was found on the lower parts of sand grains, near to the galvanised steel sheet (Figs. 5-8). The paint system thickness varies between approx 500 to $700 \mu \mathrm{m}$ on a metal surface and approx $50 \mu \mathrm{m}$ on the upper part of sand grains. Application of sand grains into a wet paint layer caused a decrease in the thickness of the paint layer under the sand grains nearing to zero.

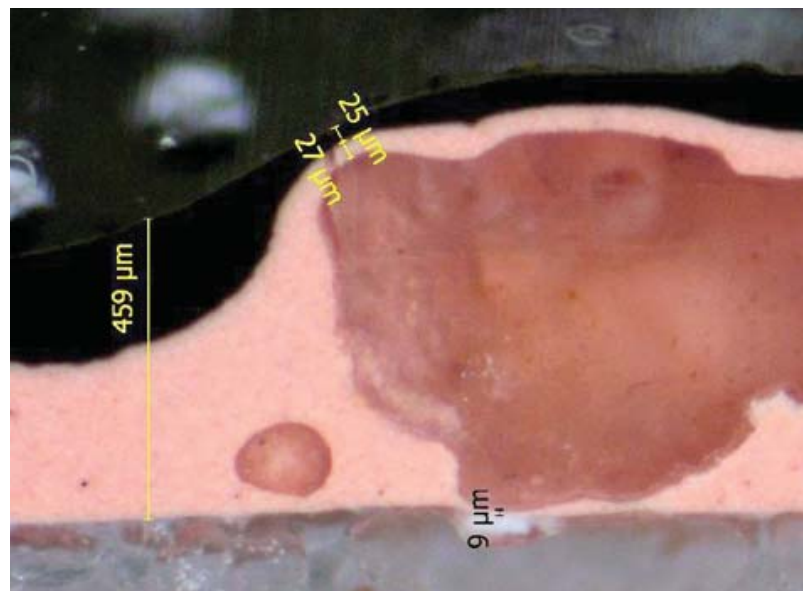

Fig. 7. A layer thickness of $27+25 \mu \mathrm{m}$ on the upper part of a sand grain

Obr. 7. Vrstva $s$ tlouštkou $27+25 \mu m$ na vrchní části zrna písku

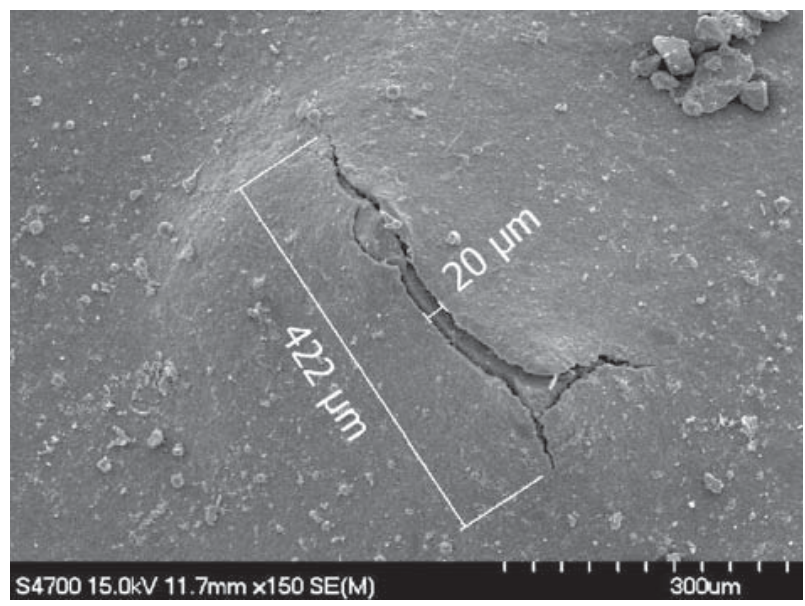

a)

\section{SEM microscopy of the delaminated anti-sliding paint system}

More detailed images with a higher magnitude and significantly higher harshness proved the negative effect of high non-uniformity of thickness of layers of $2 \mathrm{~K}$ paints with pasted sand grains. There were found highly developed cracks in the paint systems, on the upper parts of sand grains, and also the cracks in the initial stage (Fig. 9).

\section{Comparative visualisation of delamination intensity in different paint systems by means of water vapour diffusion}

The main aim of this experiment was the microscopyindependent verification of the negative effect of a step

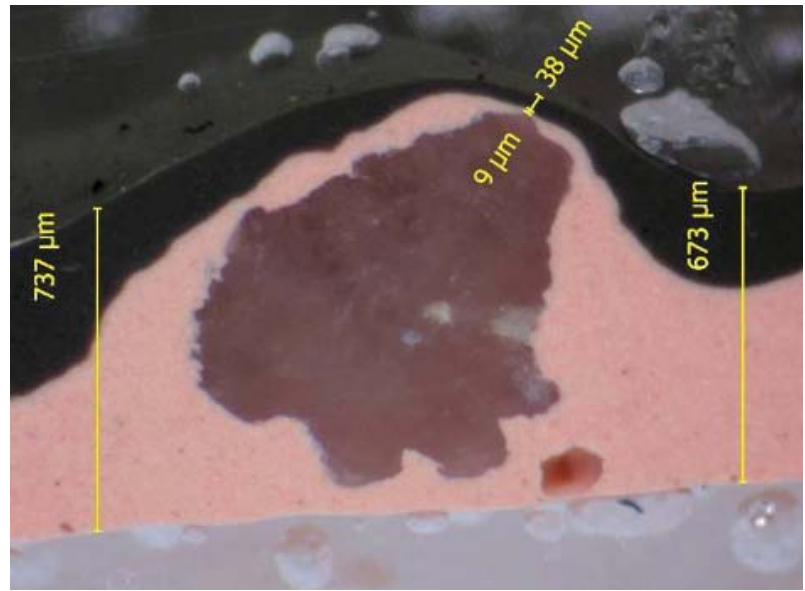

Fig. 8. A layer thickness of $9+38 \mu \mathrm{m}$ on the upper part of a sand grain

Obr. 8. Vrstva s tlouštkou $9+38 \mu m$ na vrchní části zrna písku

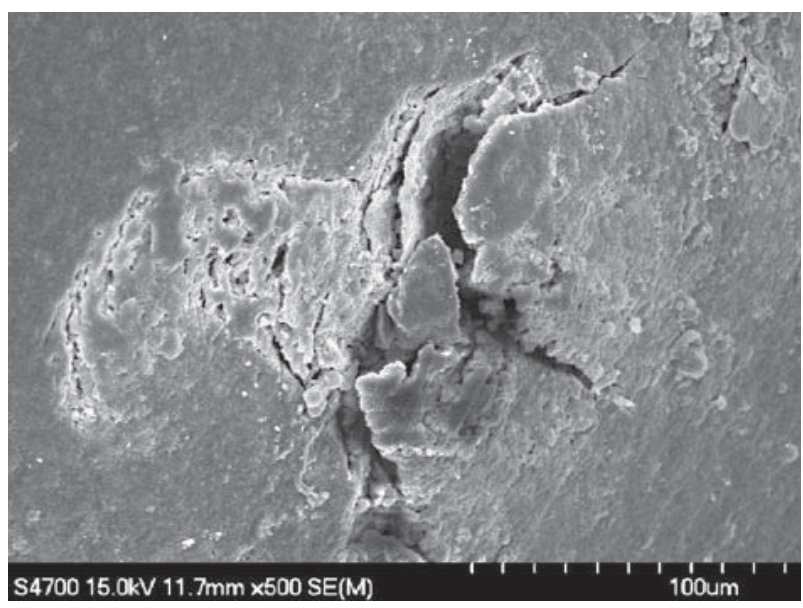

b)

Fig. 9. Cracks development in the paint system layer on the side and the top of a sand grain, 150x and 500x magnitude Obr. 9. Praskliny vytvořené ve vrstvě nátěrového systému vedle a nad zrny písku, 150x a 500x zvětšeno 
change in paint layer thickness on durability of a paint system. Significant pain system delamination was found around sand grains after 5 test cycles (Fig. 11) and a paint system layer got delamined in approx $75 \%$ of the area after 13 test cycles (Fig.13). The reference paint without any anti-sliding modification did not show any delamination after the test (Figs. 10 and 12).

The paint layers were removed from the ring areas for both paint systems after their cyclic exposure to changing temperatures and humidity levels, and the substrate glass surfaces were visually evaluated in a careful manner.

The glass surface covered with a modified antisliding layer was constantly damaged by relative deep scratches caused by sand grains pasted into the paint layers (Figs. 14 and 16). There were not found any defects on the glass surface covered by the original paint system after its removal (Fig. 15). This fact helps to fully clarify

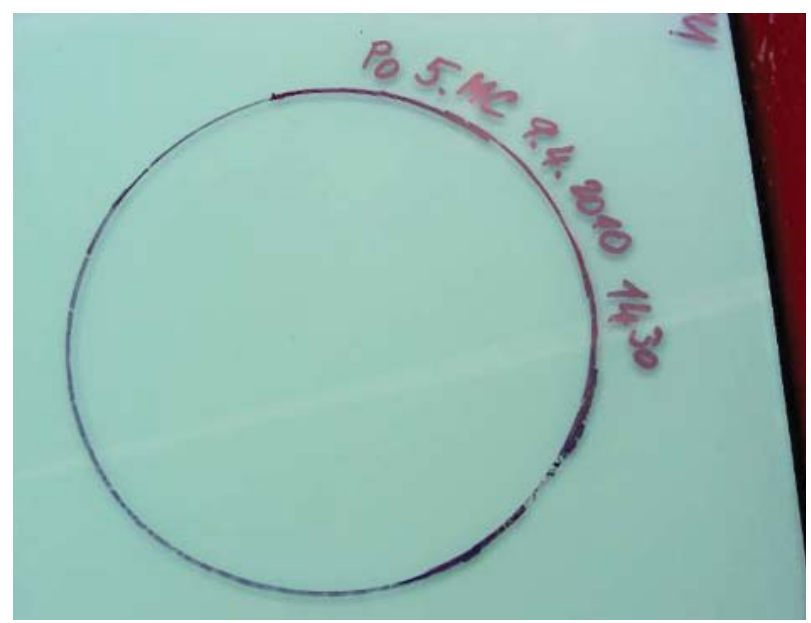

Fig. 10. No paint system delamination after 5 cycles Obr. 10. Nátěrový systém bez delaminace po 5 cyklech

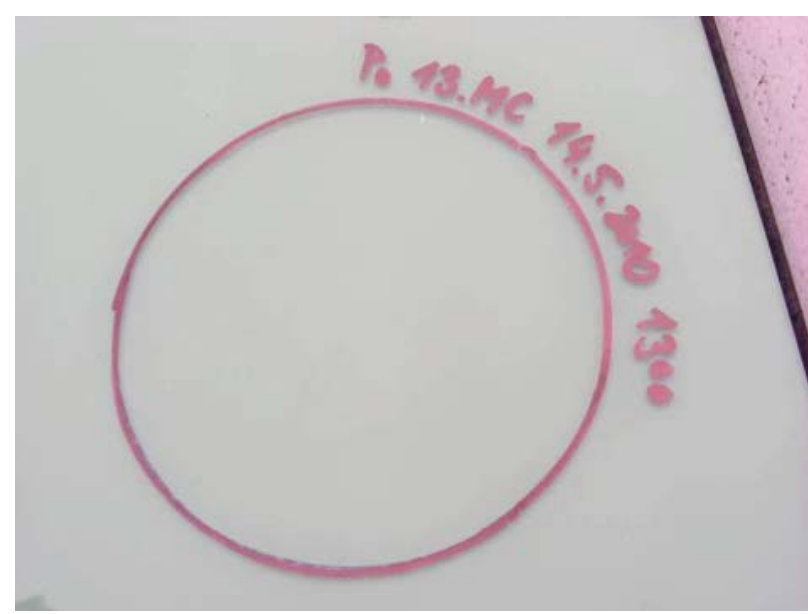

Fig. 12. No paint system delamination after 13 cycles Obr. 12. Nátěrový systém bez delaminace po 13 cyklech and understand the cause leading to occurrence of the self-destructive mechanism which had been accidentally but really formed in the modified anti-sliding paint system.

\section{Comparison of delamination intensity in different paint systems after accelerated corrosion tests}

The sheet sample with anti-sliding modification shows total delamination of a paint system layer after its exposure to an accelerated corrosion test according to ISO 9227. The modified anti-sliding paint system showed an intensive corrosion attack on the zinc layer, which locally led to red steel corrosion product occurrence (Figs. 17-20). Sharp sand grains create defects in a relatively thin zinc coating. The paint layer was removed from the non-modified painted sheet by means of an organic thinner after the accelerated test. The zinc layer

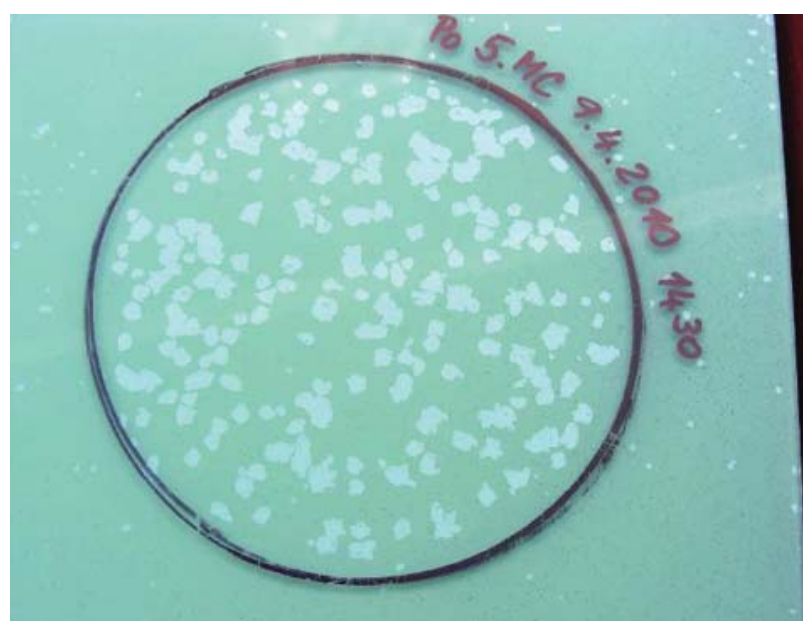

Fig. 11. Significant paint system delamination after 5 cycles Obr. 11. Významná delaminace nátěrového systému po 5 cyklech

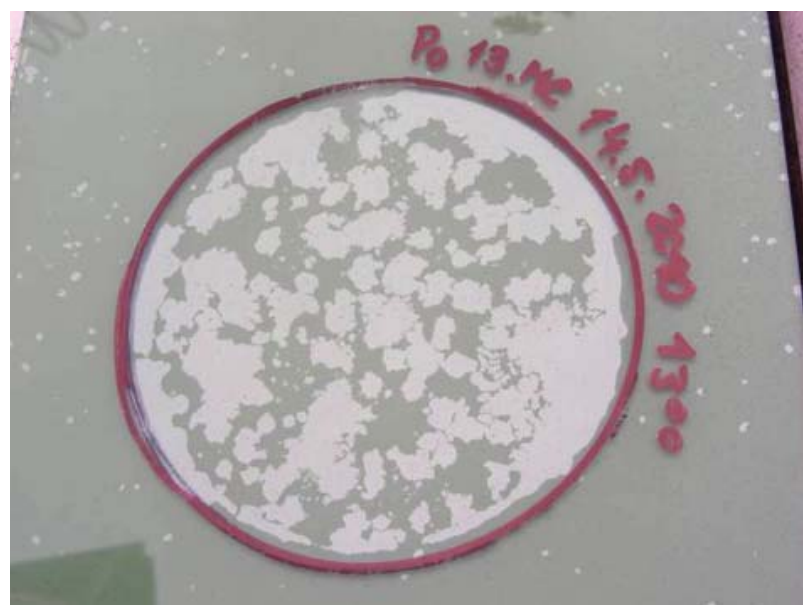

Fig. 13. Non-acceptable paint system delamination after 13 cycles

Obr. 13. Neprijatelná delaminace nátěrového systému po 13 cyklech 


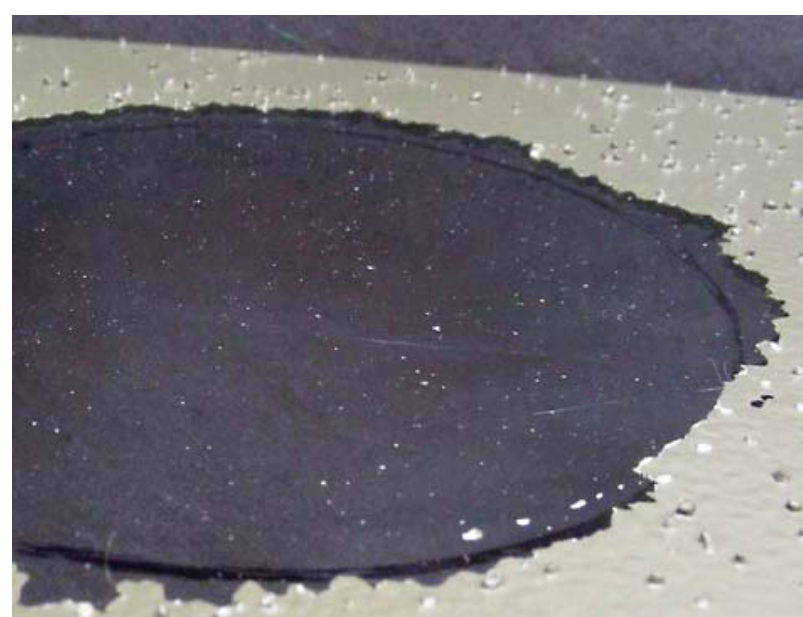

Fig. 14. No paint system delamination after 5 cycles Obr. 14. Nátěrový systém bez delaminace po 5 cyklech

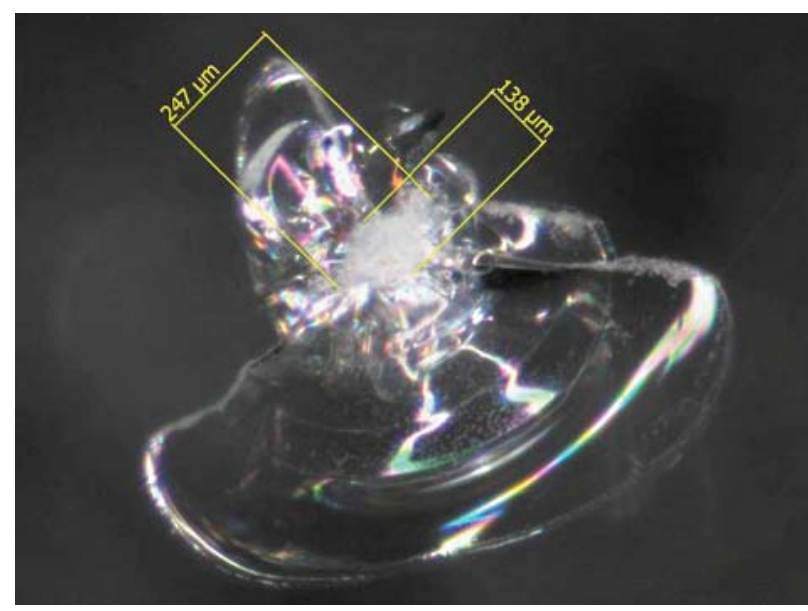

a)

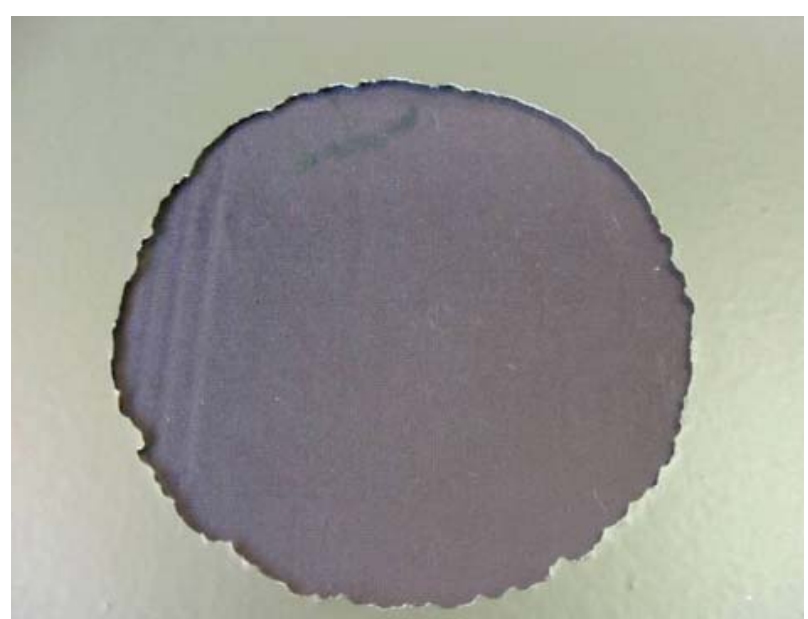

Fig. 15. Significant paint system delamination after 5 cycles Obr. 15. Významná delaminace nátěrového systému po 5 cyklech

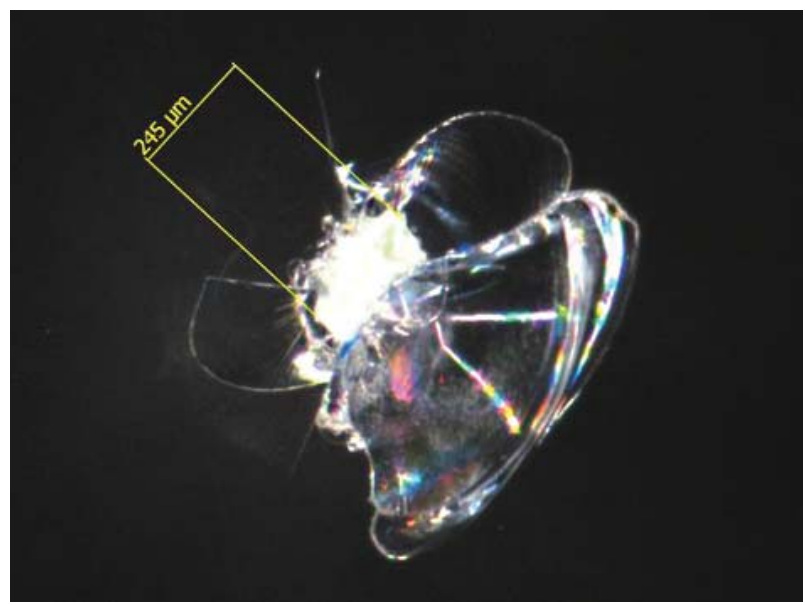

b)

Fig. 16. Measuring of the fragmentation scratch of glass caused by the pressure of a sand grain pasted into the paint system Obr. 16. Měření tř́štivého vrypu ve skle vlivem tlaku pískového zrna zapracovaného do NS

on this sample was neither corroded nor steel substrate. The accelerated corrosion test was the third individual test to prove negative effects of modification of the original paint system.

\section{DISCUSSION}

Significant difference in the behaviour of both paint system types was found. Optical microscopy of a delaminated anti-sliding paint system very clearly showed extreme non-uniformity of layer thickness near pasted sand grains. All identified cracks in the paint system were localised in the areas open to outdoor atmosphere which results in possible rain precipitation freely penetrating into paint layers and accelerated corrosion degradation of the duplex paint system. The original paint system showed excellent corrosion protection of substrate metal but the modified anti- sliding paint system showed an intensive corrosion attack on the zinc layer locally led to red steel corrosion product occurrence.

The cyclic tests performed on the glass substrate showed excellent outcomes and different results of visualisation surpass all earlier expectations. Evaluation of the glass surface after cyclic tests provides more information for understanding the reason of premature failing of a paint system. All performed individual tests prove the negative effect of modification of the original paint system.

\section{CONCLUSIONS}

There are frequent occurrences of many modifications of paint systems because their development and application is required by the market need to sell new products. It is supposed that paint systems are simply the 


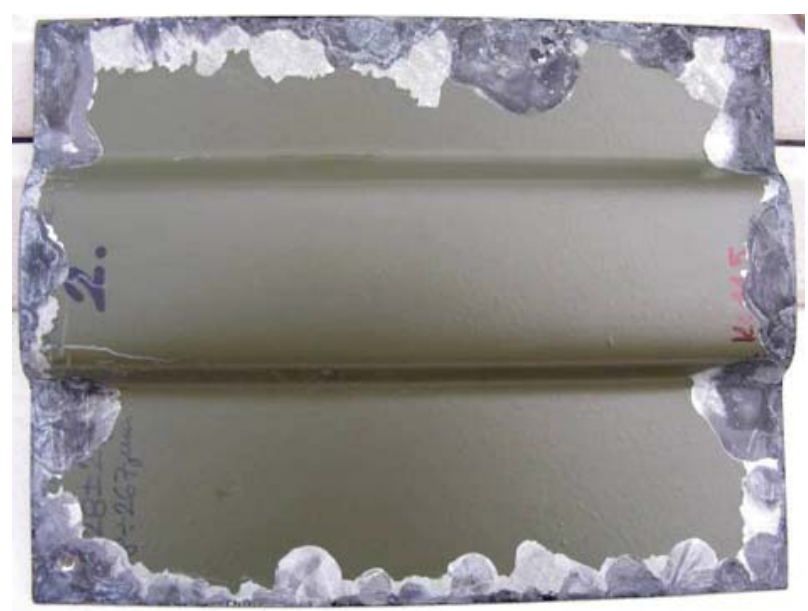

Fig. 17. 1200 hrs at NSS, no corrosion or delamination in the area

Obr. 17. 1200 h ve zkoušce NSS, bez korozního napadení a delaminace $v$ ploše

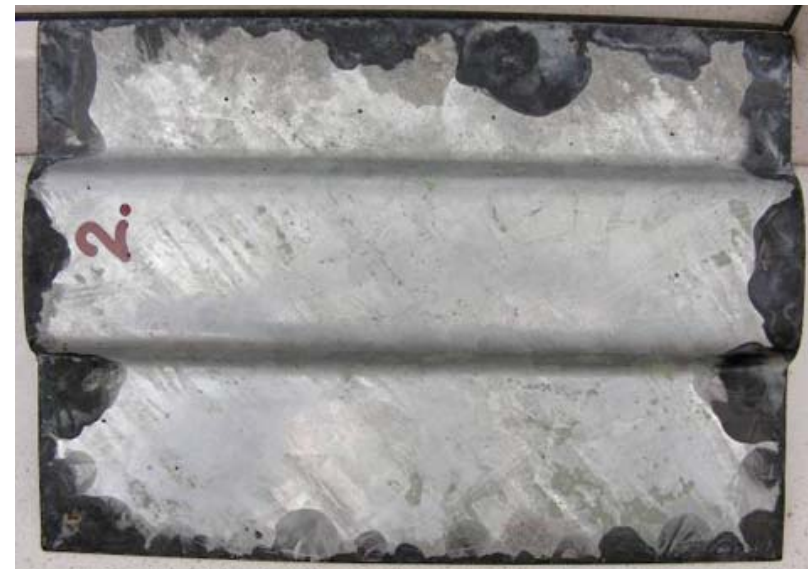

Fig. 19. The zinc layer without corrosion in the area under the paint

Obr. 19. Zinkový povlak pod vrstvou nátěrového systému bez korozního napadení

systems which may easily be modified. But interventions into testified formulations are often done without any detailed study of properties of the newly modified systems. It is supposed that "minor" modifications cannot significantly change the physical and chemical characteristics of applied paint systems. This simplified approach brings a cardinal risk of occurrence of a premature failure of paint systems. The presented study is a demonstrative example.

The conducted study was elaborated in every detail and with an interdisciplinary approach with the aim to show that the application of a highly sophisticated technique as for example SEM was not sufficient to find the full range of reasons of the failure, but it was necessary to find and use non-standardized, very non-traditional

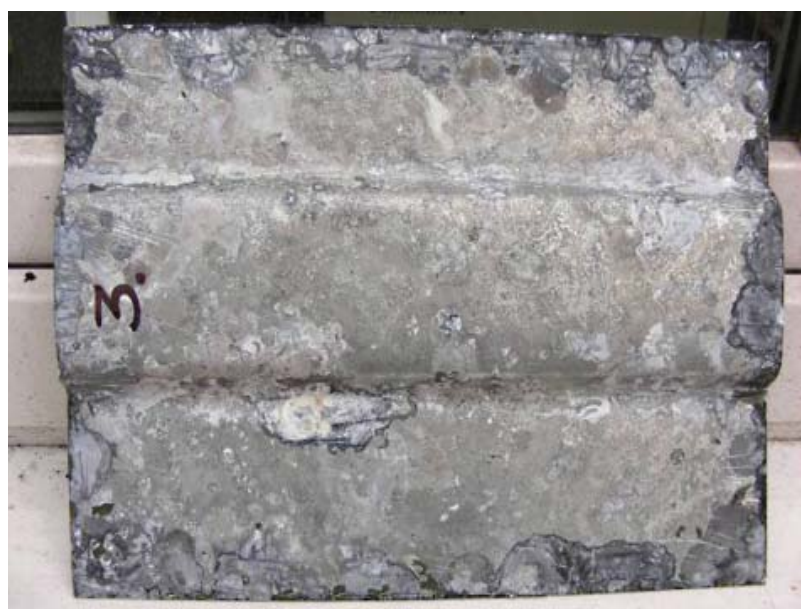

Fig. 18. $1200 \mathrm{hrs}$ at NSS, total delamination of the paint system, a corrosion attack on the zinc layer Obr. 18. 1200 h ve zkoušce NSS, úplná delaminace nátěrového systému, korozní napadení zinkového povlaku

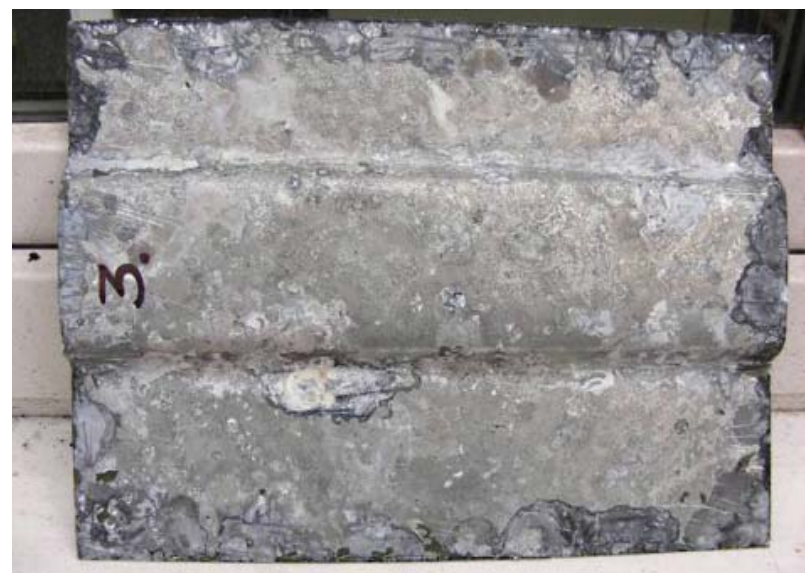

Fig. 20. Intensive corrosion of the zinc layer in the area under the paint

Obr. 20. Zinkový povlak pod vrstvou nátěrového systému s intenzivním korozním napadením

laboratory methods for the testing of paints on glass substrate, which finally helped to complete the mosaic of all effects leading to the creation and impact of the self-destroying mechanism in a modified paint system. All these methods are based on physical properties of painting systems, e.g. diffusion, and basic principles of corrosion protection.

\section{Acknowledgements}

The study was drawn up within the frame of Project IP 6/2016 financed by the Ministry of Industry and Trade of the Czech Republic. 